\title{
EDITORIAL
}

\section{BETTY J. MEGGERS Y SU TRASCENDENTAL DEDICACIÓN HEMISFÉRICA A LA ARQUEOLOGÍA LATINOAMERICANA}

\author{
BETTY J. MEGGERS AND HER TRASCENDENTAL HEMISPHERIC \\ DEDICATION TO LATIN AMERICAN ARCHAEOLOGY
}

\author{
Lautaro Núñez $z^{1}$, Abelardo Sandoval ${ }^{2}$, Vivien G. Standen ${ }^{3}$ y Calogero M. Santoro ${ }^{4,5}$
}

Betty J. Meggers, figura emblemática de la arqueología del siglo veinte, partió el día 2 de julio de 2012. Su salud contrastaba con la lucidez y agudeza intelectual que marcó toda su carrera en el National Museum of Natural History (NMNH) iniciada el 23 de junio de 1939 según nota de Alexander Wetmore, Secretario Asistente del Smithsonian Institution (SI), en la que aceptaba a Betty, de 17 años de edad, para trabajar como voluntaria en la División de Arqueología del Museo. Setenta años más tarde, el 10 de noviembre de 2009, en ceremonia privada en el Museo, se celebró y reconoció esta misión que mantuvo hasta el final. Daniel Rogers, Director del Departamento de Antropología, resaltó la proyección internacional que Betty le había dado al Museo y a la disciplina. Ella, manteniendo su perfil bajo, agradeció la suerte de estar rodeada de amigos y colegas (Watanabe 2012).

Esta insularidad marcó la vida de Betty, quien, desde su oficina en el tercer piso del NMNH en Washington DC, provocó los cimientos de la antropología, con proposiciones que generaron más adversarios que adeptos y la mantuvieron, a veces en un clima académico más bien adverso. Nuestro testimonio está destinado no sólo a develar la tenaz vida académica de Betty (Figura 1), desde fuera de la esfera de la arqueología norteamericana, sino también su rol inspirador, articulador y apoyador de grandes círculos virtuosos de científicos jóvenes y experimentados que traspasaron las fronteras de varios países a lo largo de Centroamérica, el Caribe y Sudamérica. Existe consenso que Betty
Betty J. Meggers, a prominent figure in 20th century archaeology, left us on July 2, 2012. At the time of her death, her health contrasted with her lucidity and intellectual acuity which marked her entire career at the National Museum of Natural History (NMNH); a vocation which began on June 23, 1939, according to a note by Alexander Wetmore, Assistant Secretary of the Smithsonian Institution (SI) at the time, accepting a 17 year old Betty to work as a volunteer in the Archaeology Division of the Museum. Seventy years later, on November 10, 2009, in a private ceremony at the Museum, her scientific mission, which she carried out until the end, was celebrated and recognized. Daniel Rogers, Director of the Anthropology Department, highlighted the international outlook Betty had given the Museum and the discipline. Maintaining her low profile, Betty gave thanks for being lucky enough to be surrounded by friends and colleagues (Watanabe 2012).

Despite Betty's reserved life style, from her office on the third-floor of the NMNH in Washington $D C$ she shook the foundations of anthropology with propositions that created more critics than followers, which sometimes subjected her to a rather unfriendly academic environment. Our testimony aims to highlight not only Betty's tenacious academic life (Figure 1) from a perspective outside of American archaeology, but also the central role she played in inspiring, articulating and supporting virtuous circles of young and experienced scientists from Central America, the Caribbean and South

1 Instituto de Investigaciones Arqueológicas y Museo, Universidad Católica del Norte, calle Gustavo Le Paige s/n, San Pedro de Atacama, Chile. lautaro.nunez@ hotmail.com

2 Smithsonian Institution, National Museum of Natural History, $10^{\text {th }}$ Street \& Constitution Ave, NW, Washington D.C., 20560, USA.sandovaa@si.edu

Departamento de Antropología, Universidad de Tarapacá, 18 de Septiembre 2222, Arica, Chile. vivien.standen@gmail.com Instituto de Alta Investigación, Universidad de Tarapacá, Antofagasta 1520, Arica, Chile. calogero_santoro@yahoo.com Centro de Investigaciones del Hombre en el Desierto, Av. General Velásquez 1775, Edificio CIHDE, Piso 2, Arica, Chile. csantoro@cihde.cl 


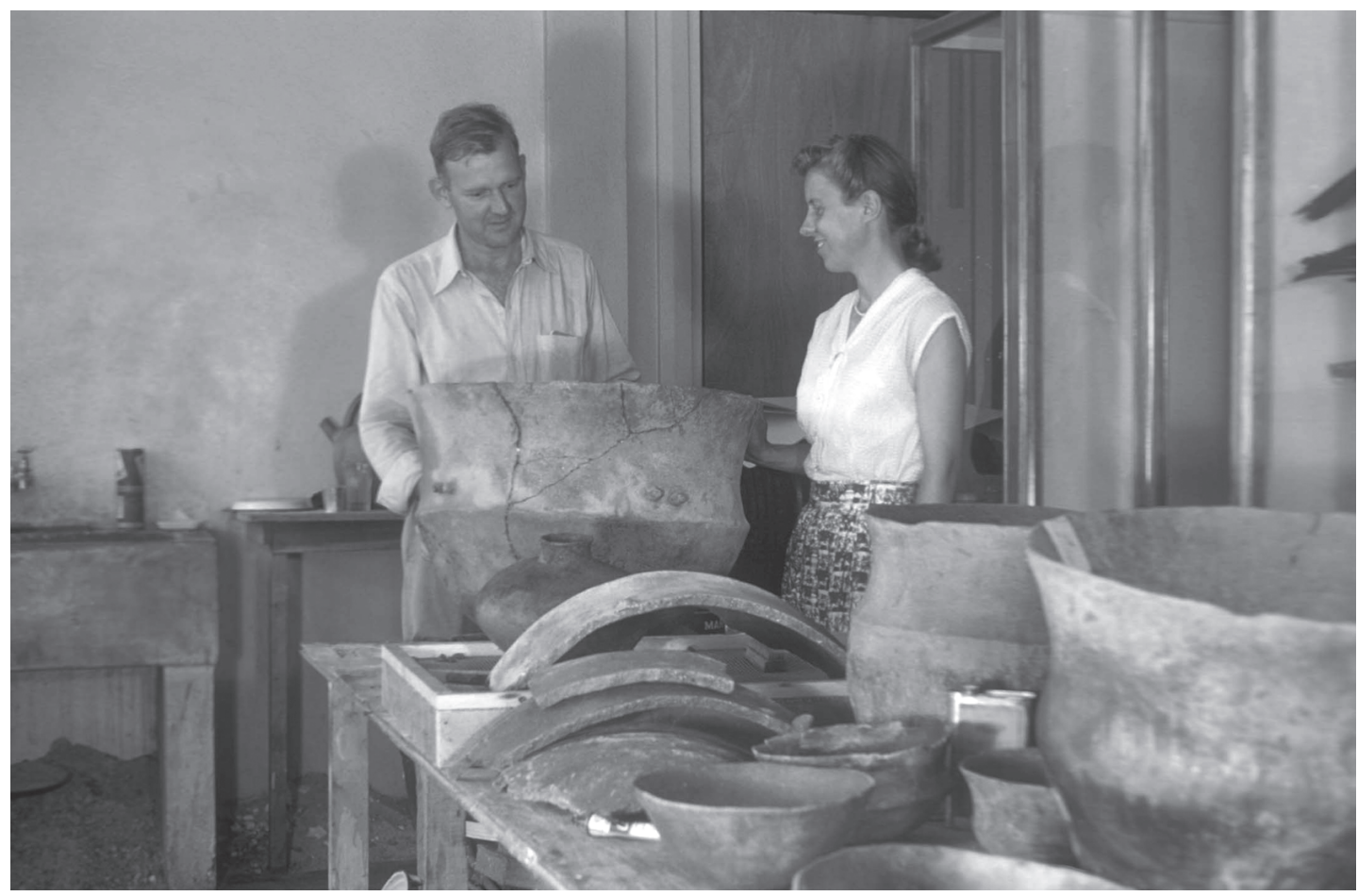

Figura 1. Betty Meggers y Clifford Evans en el laboratorio del British Guiana Walter Roth Museum, en el estudio de la cerámica Annai (febrero 1953; foto archivo Betty Meggers, editada por Paola Salgado).

Betty Meggers and Clifford Evans at the laboratory of the British Guiana Walter Roth Museum, studying the Annai pottery (February 1953; photo Betty Meggers archive, edited by Paola Salgado).

Meggers fue una investigadora excepcional por la manera como junto a su esposo y colega, Clifford Evans, establecieron nodos de colaboraciones con colegas latinoamericanos que perduraron en el tiempo (Almeida Echeverría 2012; Arellano y Wilkerson 2012; Sandoval 2012). Betty y Cliff pusieron al servicio de la región al sur del Río Grande el conocimiento antropológico de la ciencia norteamericana, estableciendo una relación de pares, con la aspiración de crear junto con nosotros, condiciones favorables para hacer lo que simplemente llamaban "una buena ciencia", inspirada en los datos. Ayudaron a gestionar recursos para apoyar proyectos arqueológicos, publicaciones, traducciones, dataciones radiocarbónicas, becas de perfeccionamiento (otorgada a uno de los autores, VS, para sus estudios de posgrado). Varias generaciones de arqueólogos latinoamericanos han pasado temporadas de investigación con las colecciones y biblioteca del Museo y como buenos anfitriones, no hubo visitante a Washington DC que no fuera invitado por Cliff y Betty, a deleitarse con una obra teatral
America. There is consensus that Betty Meggers was an exceptional researcher because of the way she and her husband and colleague, Clifford Evans, created lasting collaborative networks with LatinAmerican scholars (Almeida Echeverría 2012; Arellano and Wilkerson 2012; Sandoval 2012). Betty and Cliff made the anthropological knowledge of North American science available to scholars south of the Rio Grande, establishing a peer-based relationship, in the hope of generating favorable conditions to create what they simply referred to as "good science" or data-driven science. They helped manage resources to support archaeological projects, publications, translations, radiocarbon dating, and fellowship grants (i.e. awarded to one of the authors, V.S., for graduate studies). Several generations of Latin American archaeologists spent periods researching the collections and studying in the library of the Museum. Cliff and Betty were superb hosts. There were no visitors to Washington $D C$ who were not invited by them to enjoy a play or a musical at Arena Stage, the Shakespeare 
o musical al Arena Stage, al Shakespeare Theater, al Opera House o al Kennedy Center. Amantes de la 'comida picante' o spicy food (como Betty solía decir) de la culinaria latinoamericana, no podían faltar en su restaurante favorito unas margaritas o un pisco sour, que acompañaran una conversación casi siempre académica, o sobre sus lecturas favoritas de historias de ficción, étnicas y policiales.

Betty impresionó por su apariencia frágil y una voz apenas perceptible que no armonizaba con su tremenda creatividad científica que fue reconocida por diversos premios académicos en Antillas Menores, Argentina, Brasil, Chile, Cuba, Ecuador, Granada, Guyana, México, Panamá, Perú, Uruguay, Venezuela, Estados Unidos y organismos como la OEA; a lo que se agregan seis Doctorados Honoris Causa de universidades en Argentina, Brasil y Ecuador. En Chile, el 18 de julio de 1985 fue condecorada con la "Orden al Mérito Bernardo O'Higgins", en el grado de Comendador, lo que fue refrendado al año siguiente por la Sociedad Chilena de Arqueología y más tarde, 1996, incorporada como Miembro Honoraria. Perú le otorgó en 1988 la "Condecoración de Gran Oficial de la Orden al Mérito", alta distinción otorgada por este Estado a nacionales y extranjeros por notables servicios prestados al país. En su propio país fue distinguida por la Washington Academy of Sciences, American Anthropological Association, National Science Foundation, Battelle Memorial Institute, National Geographic Society, Smithsonian Institution, entre otros.

Estos reconocimientos los exhibía Betty en una pared de su oficina junto al mesón-estante donde se ordenaban sus clásicos sobres amarillos, en los que despachaba una variedad de publicaciones a sus amigos y colegas. Allí también se acumulaban varios metros lineales de libros, separatas y manuscritos que recibía a diario; en un tránsito "hormiga" de miles de datos e ideas redistribuidos por Betty. Recibir uno de estos sobres era imaginar a Betty y Cliff mirando desde sus escritorios cómo fluía esta red de intercambio transcontinental, mucho antes de las redes computacionales y archivos PDF. El epistolario de Betty contiene también detalles de las tensiones que han entreverado la arqueología latinoamericana y norteamericana y los avatares políticos de investigadores perseguidos durante la convulsionada segunda mitad del siglo veinte (Metcalf y Huntington 1995).
Theatre, the Opera House or the Kennedy Center. Both lovers of spicy food (as Betty used to say) from Latin American cuisine, there was always a pisco sour or a margarita in their favorite restaurant to accompany an academic conversation, or discussions over her favorite science-fiction, ethnic and crime books.

Betty impressed with her fragile appearance and barely audible voice, which contrasted with her tremendous scientific creativity recognized by several academic awards in Antilles, Argentina, Brazil, Chile, Cuba, Ecuador, Granada, Guyana, Mexico, Panama, Uruguay, Venezuela, The United States and international organizations such as OAS. She also received six Doctorates Honoris Causa from universities in Argentina, Brazil and Ecuador. In Chile, on July 18, 1985, she was awarded the "Order of Merit Bernardo O'Higgins", in the degree of Commander, which was endorsed the following year by the Chilean Society of Archaeology. Later, in 1996, she was incorporated as Honorary Member into the Society. In 1988, Peru awarded her the "Decoration of Grand Officer in the Order of Merit", a high distinction awarded by this State to nationals and foreigners for distinguished services rendered to the country. In her own country she was distinguished by the Washington Academy of Sciences, the American Anthropological Association, the National Science Foundation, the Batelle Memorial Institute, the National Geographic Society, the Smithsonian Institute, among other institutions.

All these awards were hanging on a wall in her office by a shelf, where the familiar yellow manila envelopes that she used to mail a variety of publications to her friends and colleagues were stocked. There she also kept several rows of books, offprints and manuscripts that she received daily, creating a small-scale transit of thousands of ideas and large amounts of data redistributed by Betty through her manila envelopes. Receiving one of these envelopes was to imagine Betty and Cliff looking from their desks at how this network of transcontinental exchange flowed, long before computer networks and PDF files. Betty's archives included letters that contain details of the tensions in Latin American and North American archaeology and the political vicissitudes of researchers persecuted during the troubled second half of the 20th century (Metcalf and Huntington 1995).

Betty was born in Washington DC, on December 5, 1921, to the physicist William F. Meggers and 
Betty nació en Washington DC, el 5 de diciembre de 1921. Sus padres fueron el físico William F. Meggers y Edith R. Meggers. Realizó sus estudios de pregrado en antropología en la Universidad de Pennsylvania en 1943. En ese contexto estudió la colección alfarera Beal-Steere de la isla Marajó (Brasil), conservada en la Universidad de Michigan; de lo que resultó su primera publicación en Papers of the Michigan Academy of Science, Arts and Letters, en 1945. A ello siguieron otras publicaciones en Ethnology y American Anthropologist, entre los años 1945 y 1948, ligadas a la arqueología sudamericana. En 1944 ingresó a la Universidad de Columbia donde en 1945 conoció a Clifford Evans, y a su gran amigo argentino y condiscípulo, nuestro querido Alberto Rex González (Dillehay 2012; Núñez 2000; Rivera 2012). Desde esa época constituyeron un binomio inseparable, que forjó una entidad humana y científica común, a pesar de las diferencias de estilos en las argumentaciones y posturas teóricas. Juntos realizaron trabajos de campo en Amapá para sus tesis de doctorado, grado que Betty obtuvo en 1952 con la tesis The Archaeological Sequence on Marajo Island, Brazil with Special Reference to the Marajoara Culture.

En 1952, ambos continuaron con sus investigaciones arqueológicas en la cuenca amazónica de Guyana (Guayana Británica), compartiendo sus estrategias tanto arqueológicas como etnográficas entre las comunidades Waiwai (Figura 1). Betty continuó sus estudios sobre los procesos culturales en la isla Marajó, basada en sus investigaciones iniciadas en 1948. Luego en septiembre-noviembre de 1954 concentraron sus esfuerzos metodológicos en la costa ecuatoriana junto a Emilio Estrada, con quien trabaron una profunda amistad. De allí surgió la definición de las primeras secuencias estratigráficas para el período Formativo con respaldo radiocarbónico y clasificación cerámica a través de su método de seriación. En octubre-diciembre del año 1956 realizaron exploraciones y excavaciones a lo largo del río Napo, región oriental de Ecuador. En ese contexto organizaron, el 7 de febrero de 1957, la Mesa Redonda Internacional de Arqueología Ecuatoriana, auspiciada por la Casa de la Cultura Ecuatoriana, Smithsonian y el Núcleo del Guayas ${ }^{1}$. Definieron la primera estructura cronológica y cultural de trascendencia nacional e internacional para el litoral ecuatoriano (precerámico, formativo temprano, medio y tardío, desarrollo regional e integración). Entre los años 1957 y 1961 desarrollaron expediciones arqueológicas en
Edith R. Meggers. She finished her undergraduate studies in anthropology at the University of Pennsylvania in 1943. In that context, she studied the Beal-Steere collection of pottery from Marajo Island (Brazil), kept at the University of Michigan. This study resulted in her first publication in the Papers of the Michigan Academy of Science, Arts and Letters, in 1945. Other publications linked to South American Archaeology followed in Ethnology and American Anthropologist, between the years 1945 and 1948. In 1944 she entered Columbia University, where, in 1945, she met Clifford Evans and her great Argentinean friend and fellow student, our dear Alberto Rex González (Dillehay 2012; Núñez 2000; Rivera 2012). Since then, Betty and Cliff became an inseparable pair, which forged a common human and scientific entity, despite their differences in argumentative and theoretical styles. Together, they carried out fieldwork in Amapá for their doctoral dissertations. In 1952 Betty was awarded her doctoral degree with the thesis entitled The Archaeological Sequence on Marajo Island, Brazil with Special Reference to the Marajoara Culture.

In 1952, they both continued their archaeological research in the Amazon basin in Guyana (former British Guiana), sharing their archaeological and ethnographic strategies among the Waiwai communities (Figure 1). Based on her research initiated in 1948, Betty continued her studies on the cultural processes in Marajo Island. In September-November 1954, they focused their methodological efforts on the Ecuadorian coast together with Emilio Estrada, with whom they formed a deep friendship. From there emerged the definition of the first stratigraphic sequences for the Formative period, backed by radiocarbon and ceramic classification using their seriation method. In October-December 1956, they explored and excavated along the Napo River, eastern region of Ecuador.

In that context, on February 7th 1957, they organized the International Roundtable on Ecuadorian Archaeology, sponsored by the Ecuadorian House of Culture, the Smithsonian and the Guayas Nucleus ${ }^{l}$. They defined the first chronological and cultural structure of national and international importance for the Ecuadorian littoral (preceramic, early, middle and late formative, regional development and integration). Between the years 1957 and 1961 they carried out archaeological expeditions along the Ecuadorian coast (Evans and Meggers 1968). Working together with Emilio Estrada, who had 
la costa ecuatoriana (Evans y Meggers 1968). Juntos con Emilio Estrada, quien había avanzado en la idea de vincular la cultura Valdivia con aquella Jomón de Japón, plantearon la hipótesis de posibles contactos transpacíficos (Estrada et al. 1962). En efecto, en 1963 realizaron estudios comparativos con colecciones Jomón en Tokio, y a consecuencia de ello en 1964, en el 36 Congreso Internacional de Americanistas de Sevilla, España, sostuvieron la tesis de contactos transpacíficos a través de los pescadores complejos de Jomón, del antiguo Japón, carentes de agricultura, quienes habrían arribado a la costa ecuatoriana con cerámica y litos pulidos. Estos estudios pioneros abrieron nuevas posibilidades interpretativas para la colonización de América con posterioridad a la inmigración por el istmo de Bering a finales del Pleistoceno (Meggers 1987), propuesta controversial que mantuvo hasta el final de su vida. No obstante lo anterior, para Ecuador destacan una serie de notables monografías y trabajos de síntesis publicados en español e inglés, sobre sus investigaciones en Valdivia y Machalilla (Meggers et al. 1965; Meggers y Evans 1965). En 2006 la comuna de Valdivia le otorgó la Condecoración al Mérito Científico (Kaupp 2006).

Betty fue una notable estudiosa del campo de la biología cuyos principios no sólo utilizó para estructurar su metodología arqueológica, sino que además incorporó el conocimiento ecológico y los cambios ambientales como factores para comprender y explicar las transformaciones y continuidades culturales y demográficas de las poblaciones prehispánicas (Meggers 1954). Un ejemplo de esta visión fue el perfeccionamiento del método cuantitativo, propuesto por James Ford para el análisis de cerámica, que aplicó luego para definir cambios sociales entendidos como procesos evolutivos. Esta metodología y su sustento teórico, que no dejaron de ser controversiales también, circuló en forma de manual mimeografiado (Meggers 1967; Meggers y Evans 1967; Meggers y Evans 1969).

La participación de los Evans en la problemática arqueológica de Brasil se concretó a través de programas de investigación, la formación de cuadros científicos y el establecimiento de secuencias prehistóricas y contextos debidamente contrastados; integrando recursos financieros norteamericanos y locales. Con sus colegas y amigos brasileños crearon primero el Programa Nacional de Pesquisa Arqueológica (PRONAPA 1965) y, posteriormente, el Programa Nacional de Pesquisa Arqueológica na Bacia Amazônica (PRONAPABA advanced in the idea of linking the Valdivia culture to the Jomon culture of Japan, they put forward the hypothesis of possible transpacific contacts (Estrada et al. 1962). In fact, in 1963 they carried out comparative studies with Jomon collections in Tokyo. As a result, in 1964, at the 36th International Congress of Americanists, in Seville, Spain, they presented the thesis of transpacific contacts through complex fishermen of Jomon, from Ancient Japan, who lacked agriculture and would have arrived at the Ecuadorian coast with ceramic and polished lithics. These pioneer studies opened up new interpretive possibilities for the colonization of America after the immigration through the Bering Isthmus during the late Pleistocene (Meggers 1987). This was a controversial proposal that she defended until the end of her life. Nevertheless, for the Valdivia and Machalilla case of Ecuador a series of notable monographs and synthesis works were published in Spanish and English (Meggers et al. 1965; Meggers and Evans 1965). In 2006 the commune of Valdivia awarded her the Decoration for Scientific Merit (Kaupp 2006).

Betty was a remarkable scholar in the field of biology. She not only used biological principles to structure her archeological methodology, but also incorporated ecological knowledge and environmental changes as factors to understand and explain the cultural and demographic transformations and continuities of prehispanic populations (Meggers 1954). One example of this perspective was the perfection of the quantitative method proposed by James Ford for the analysis of ceramics, which she then applied to define social changes understood as evolutionary processes. This controversial methodology and its theoretical support were distributed as a mimeographed manual (Meggers 1967; Meggers and Evans 1967; Meggers and Evans 1969).

The Evanses' involvement in the archeological studies of Brazil materialized through a series of research programs, the training of scientists and the establishment of prehistoric sequences and duly contrasted contexts, integrating North American and local financial resources. Together with their Brazilian friends and colleagues, they created the first National Program for Archaeological inquiry (PRONAPA 1965) and, later on, the National Program for Archaeological Inquiry in Bacia Amazônica (PRONAPABA 1975). At the same time, they were in charge of the Smithsonian Archaeology Program for Latin America (Sandoval 2012). 
1975). Paralelamente, mantenían el Programa de Arqueología de América Latina (Sandoval 2012).

En la Amazonía brasileña, quizás su mayor centro de atención, Betty se enfocó a describir y explicar la complejidad de las respuestas humanas a las variaciones de las condiciones ambientales del "paraíso ilusorio", como definió la foresta tropical. La valoración ecológica de la Amazonía fue para ella un caldo de cultivo para aplicar su formación biológica y antropológica, generando una visión que combinaba las acciones humanas con las condiciones de los suelos, los efectos de ENSO, la capacidad de recuperación de la vegetación y los tiempos alternados de humedad y sequía. Ciertamente, sus posiciones tuvieron detractores lo que no obliteró su aporte intelectual. De hecho, los escritos de Betty sobre las relaciones entre la sociedad y foresta tropical fueron los primeros argumentos para dar lugar a un modelo de desarrollo en la Amazonía discutido, mejorado y ampliado por nuevas generaciones de científicos (Meggers 1973; Neves 2008).

La experiencia ecuatoriana de los Evans perfeccionada con el programa brasileño, se expandió a otros países. Así, uno de los autores (LN) recuerda que en 1966 en el contexto del Congreso Internacional de Americanistas de Mar del Plata tuvo la oportunidad de conocer a los Evans, junto con Julio Montané, con quien ya estaban en contacto a raíz del sitio paleoindio de Tagua Tagua (Montané 1968). En ese encuentro estuvo también Juan Munizaga, colaborador en el proyecto de Valdivia a través del análisis de restos óseos humanos (Munizaga 1965) y, por esa época, obsesionado por los tempranos esqueletos que Junius Bird había excavado en el extremo sur de Chile, conservados en el American Museum of Natural History de Nueva York (Munizaga 1976, 1986). Estas conversaciones mantenidas a través del correo, derivaron en el desarrollo de un capítulo del Programa Paleoindio en Sudamérica de Smithsonian en Chile, liderado por Julio Montané, quien debió abandonar el país en 1973, a consecuencia del golpe militar. El programa, en consecuencia, fue desarrollado por Lautaro Núñez, a sugerencia de Jorge Iribarren en acuerdo con los Evans (Núñez 1975, 1976; Figura 2). El Programa dio lugar a las excavaciones interdisciplinarias en Quereo y en los Sitios 1 y 2 de Tagua Tagua, en Chile central. Más tarde, el Programa se extendió al desierto de Atacama, con el apoyo de Smithsonian y National Geographic Society a través de los Museos de La Serena y de San Pedro de Atacama de la Universidad
In the Brazilian Amazonia, being perhaps her main focus, Betty centered her studies on describing and explaining the complexities of human responses to the variations of the environmental conditions of this "illusory paradise", as she defined the tropical rainforest. The ecological assessment of the Amazonia became a breeding ground to apply her biological and anthropological training, giving rise to a vision that combined human actions with soil conditions, the effects of El Niño Southern Oscillation (ENSO), the capacity of vegetation recovery and the alternate periods of humidity and draught. Her theoretical approaches faced detractors, but this did not invalidate her intellectual contribution. In fact, Betty's writings about the relationships between society and tropical rainforest would give rise to the creation of a model of development in the Amazonia, discussed, improved and broadened by new generations of scientists (Meggers 1973; Neves 2008).

The Ecuadorian experience of the Evanses, perfected with the Brazilian program, expanded to other countries. Thus, one of the authors (LN) remembers that in 1966, in the context of the International Congress of Americanists, in Mar del Plata, he had the opportunity of meeting the Evanses, along with Julio Montané, with whom they had already been in contact in relation to the Tagua Tagua Paleo-Indian site (Montané 1968). Also present at that meeting was Juan Munizaga, a collaborator in the Valdivia Project with the analysis of human bone remains (Munizaga 1965) and, by that time, obsessed with the early skeletons that Junius Bird had excavated in the extreme south of Chile, which are kept in the American Museum of Natural History in New York City (Munizaga 1976, 1986). These conversations by correspondence resulted in the development in Chile of a chapter of the Smithsonian Paleo-Indian Program in South America, led by Julio Montane, who had to flee the country in 1973 after the coup d'état. Consequently, the Program was advanced by Lautaro Núñez as suggested by Jorge Iribarren to the Evanses (Núñez 1975, 1976; Figure 2). The Program gave rise to interdisciplinary excavations in Quereo and the sites 1 and 2 in Tagua Tagua, in Central Chile. Later, the Program expanded to the Atacama Desert, with support from the Smithsonian and the National Geographic Society through the Museums of La Serena and San Pedro de Atacama of Universidad del Norte. In the later, father Gustavo Le Paige made 


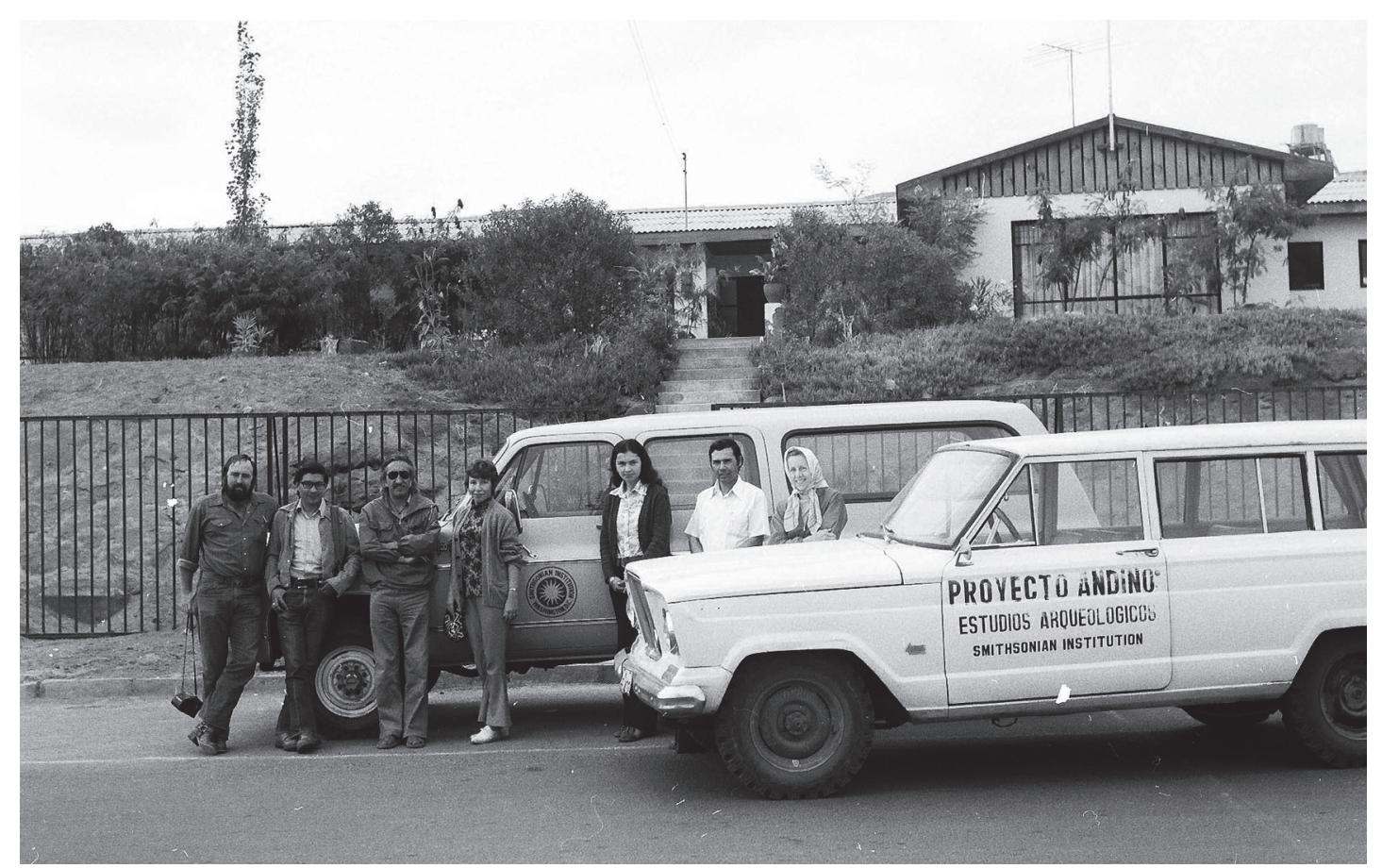

Figura 2. Integrantes del programa Paleoindio en Sudamérica, Arica febrero 1977, en frente de las actuales instalaciones del Instituto de Alta Investigación de la Universidad de Tarapacá. De izquierda a derecha Dennis Stanford (Smithsonian Institution), Miguel Pazos Rivera (Universidad de San Marcos, Perú), Lautaro Núñez (Universidad del Norte), Jeanie Stanford, Ruth Shady, Hermilio Rosas (Universidad de San Marcos) y Betty Meggers (fotografía archivo de Betty Meggers, editada por Paola Salgado). South America Paleoindian program members in Arica, February 1977, in front of the current facilities of the Instituto de Alta Investigación de la Universidad de Tarapacá. From left to right Dennis Stanford (Smithsonian Institution), Miguel Pazos Rivera (Universidad de San Marcos, Perú), Lautaro Núñez (Universidad el Norte), Jeanie Stanford, Ruth Shady, Hermilio Rosas (Universidad de San Marcos) and Betty Meggers (photo courtesy of Betty Meggers, edited by Paola Salgado).

del Norte. Allí el padre Gustavo Le Paige posibilitó contrastar sus propuestas sobre una tipología lítica de talleres-canteras de superficie, hacia sitios estratificados. En ese contexto, en 1978 se convocó un Seminario Internacional sobre tecnología Paleoindia, celebrado en Antofagasta, patrocinado por Smithsonian y la Universidad del Norte. El Taller incluyó demostraciones prácticas de tecnología lítica paleoindia a cargo de Dennis Stanford, lo que fue fundamental para la mejor comprensión de sitios talleres y canteras términos de cadenas de talla conocidos en distintas partes de Sudamérica. Los resultados de este Taller, publicados varios años más tarde, refundieron la larga historia de investigación y colaboración iniciada en Mar del Plata (Almeida Echeverría 2012; Núñez y Meggers 1987; Sandoval 2012).

La continuidad del Programa se logró gracias a nuevas gestiones de Betty y los aportes de National Geographic Society que permitió la integración de los colegas Martin Grosjean e Isabel Cartajena, con it possible to contrast his proposals about a lithic typology of surface workshop-quarries to stratified sites. In that context, in 1978 an International Seminar on paleo-Indian technology was organized, which took place in Antofagasta sponsored by the Smithsonian and Universidad del Norte. The Workshop included practical demonstrations in charge of Dennis Stanford, which was fundamental to better understand sites and quarries, in terms of lithic operational sequences, known in different parts of South America. The results of this Workshop, published several years later, unified the long research and collaboration history originated in Mar del Plata (Almeida Echeverría 2012; Núñez and Meggers 1987; Sandoval 2012).

The continuation of the program was achieved thanks to Betty's efforts and the contribution of the National Geographic Society which allowed the integration of our colleagues Martin Grosjean and Isabel Cartajena, with whom the interdisciplinary model (society-environment) for the cultural 
los que se profundizó el modelo interdisciplinario (sociedad-medioambiente) para la reconstrucción cultural y paleoambiental finipleistocénica y holocénica en las tierras medias y altas de la puna de Atacama (Meggers 1992). Cuando los resultados de esta nueva fase fueron publicados en Science (Núñez et al. 2002), Betty llamó a Lautaro para celebrar los efectos de la iniciativa articulada tres décadas antes. Fue este reconocimiento mutuo con los arqueólogos latinoamericanos lo que más estimuló a Betty a mantenerse tan activa hasta el final de sus días, sosteniendo la defensa de sus hipótesis hasta los 90 años. Con independencia de la validez o no de sus argumentos, este hecho fue una de sus últimas lecciones ejemplares (Meggers 2011; Silverman e Isbell 2008). El debate, en este sentido, con altura de miras, engrandece y optimiza la reconstrucción del pasado con los mejores aportes intergeneracionales.

Sobreponiéndose a las discrepancias que sus argumentos científicos provocaron, quedan aún vívidas las imágenes de una Betty de sonrisa alegre (Figura 3), un par de semanas antes de su deceso, and paleoenvironmental reconstruction of the late Pleistocene and Holocene in the high and middle lands of the Puna of Atacama was furthered (Meggers 1992). When the results of this new phase were finally published in Science (Núñez et al. 2002), Betty phoned Lautaro to celebrate the effects of the initiative begun three decades earlier. It was this mutual recognition with Latin American archaeologists which encouraged Betty to remain so active until the end of her days, defending her hypotheses until the age of 90, regardless of the validity of her arguments, demonstrating one of her final exemplary life lessons (Meggers 2011; Silverman and Isbell 2008).

Beyond the discrepancies that her scientific arguments provoked, the image of Betty's happy smile remains vivid (Figure 3), as she read in the recent issue of Science (June 2012), a couple of weeks before she passed away, the article Sparse pre-Columbian human habitation in western Amazonia, which partially validated her theory of a sparse human habitation of the Amazonia (McMichael et al. 2012).

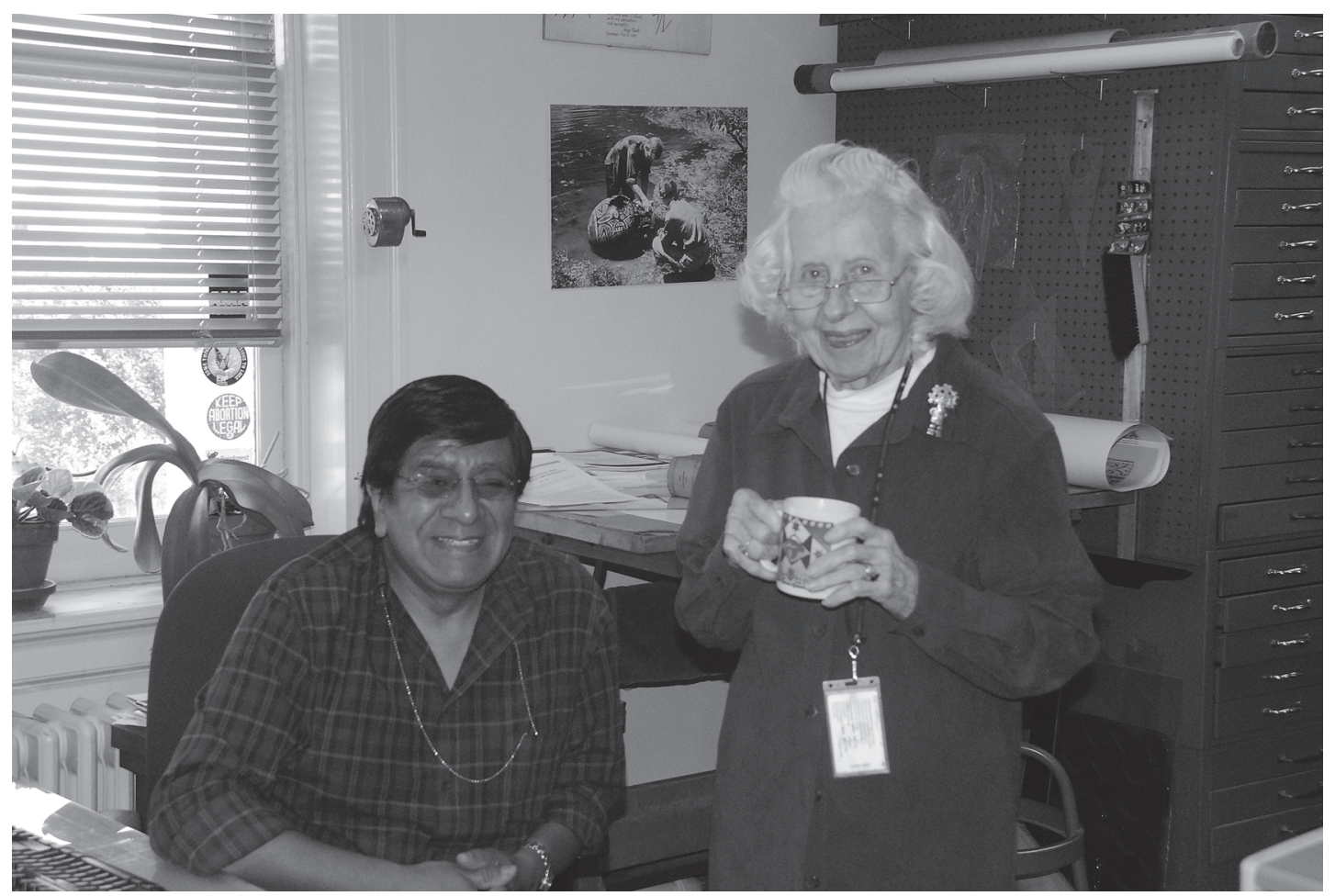

Figura 3. Betty Meggers y Abelardo 'Chinaco' Sandoval, actual presidente de la Fundación Taraxacum, agosto 2011 (fotografía Calogero M. Santoro, editada por Paola Salgado).

Betty Meggers and Abelardo 'Chinaco' Sandoval, current president of Taraxacum Foundation, August 2011 (photo by Calogero M. Santoro, edited by Paola Salgado). 
cuando leía en la más reciente publicación de Science (Junio 2012), el articulo Sparse pre-Columbian human habitation in western Amazonia, que validaba en parte su teoría de poblamiento humano disperso de la Amazonía (McMichael et al. 2012). En el medio de la preparación de publicaciones sobre sus investigaciones, Betty partió para siempre y hoy sus restos descansan en el Fort Lincoln Cemetery, de Washington, DC, su ciudad natal. En esos días, en la editorial de la Summer Edition de Anthropolog Newsletter of The Department of Anthropology National Museum of Natural History, Mary Jo Arnoldi destacó a Betty por su unwavering dedication to Latin American archaeology and her steadfast support of generations of South American archaeologists (Arnoldi 2012:1). La trascendencia de Betty y Cliff se extenderá a través de la Fundación Taraxacum, creada por ellos el 29 de enero de 1979, y presidida actualmente por su amigo y colega Abelardo Sandoval, con aportes iniciales de la Smithsonian y de su propia hacienda, para impulsar nuevas publicaciones de iniciativas arqueológicas en América y el Caribe (Figura 3).

San Pedro de Atacama, Arica, Iquique, Chile, Washington DC, USA agosto 2013.
Amidst the preparation of publications of her research, Betty departed, and her remains rest at Fort Lincoln Cemetery, Washingtom DC, her hometown. In those days, in the editorial of the Summer Edition of the Anthropolog Newsletter of The Department of Anthropology National Museum of Natural History, Mary Jo Arnoldi highlighted Betty's unwavering dedication to Latin American archaeology and her steadfast support of generations of South American archaeologists (Arnoldi 2012:1). Betty and Cliff's importance will continue through the Taraxacum Foundation, currently presided by their friend and colleague Abelardo Sandoval, and which they created on January 29, 1979, with initial contributions from the Smithsonian and their own estate, to promote new publications of archaeological initiatives in America and the Caribbean (Figure 3).

\section{Referencias Citadas}

Almeida Echeverría, J. 2012. Betty J. Meggers, Setenta y Cinco años de Trayectoria Exitosa en la Arqueología Sudamericana. Kirugraphics, Quito.

Arellano, J. y S.J.K. Wilkerson 2012. Betty J. Meggers (19212012): A Latin American perspective. Anthropolog Newsletter of The Department of Anthropology National Museum of Natural History Summer:2-3.

Arnoldi, M.J. 2012. Message from the chair. Anthropolog Newsletter of The Department of Anthropology National Museum of Natural History Summer: 1 .

Dillehay, T.D. 2012. Alberto Rex González, dean of South American archaeology. Chungara Revista de Antropología Chilena 44:205-208.

Estrada, E., B.J. Meggers y C. Evans 1962. Possible transpacific contact on the coast of Ecuador. Science 135:371-372.

Evans, C. y B.J. Meggers 1968. Archaeological Investigations on the Rio Napo, Eastern Ecuador. Smithsonian Institution, Washington D.C.

Kaupp, A. 2006. Betty Meggers honored. Anthropolog Newsletter of the Department of Anthropology National Museum of Natural History Fall:2.
McMichael, C.H., D.R. Piperno, M.B. Bush, M.R. Silman, A.R. Zimmerman, M.F. Raczka y L.C. Lobato 2012. Sparse Pre-Columbian human habitation in western Amazonia. Science 336:1429-1431.

Meggers, B.J. 1954. Environmental limitation on the development of culture. American Anthropologist 56:801-824.

- . _ 1967. The theory and purpose of ceramic analysis. Proceedings of the 2nd International Congress for the Study of the Pre-columbian Culturesi the Lesser Antilles, pp. 9-20. Barbados Museum and Historical Society, Barbados.

_ _ _ 1973. Some problems of cultural adaptation in Amazonia, with emphasis on the pre-european period. En Tropical Forest Ecosystems in Africa and South America: a Comparative Review, editado por B.J. Meggers, E.S. Ayensu y W.D. Duckworth, pp.311-320. Smithsonian Institution Press, Washington D.C.

- _ _ 1987. El origen transpacífico de la cerámica Valdivia: una reevaluación. Boletín del Museo Chileno de Arte Precolombino 2:9-31.

- _ _ 1992. Prehistoria Sudamericana. Taraxacum, Washington D.C.

_ _ _ 2011. Reseña bibliográfica Handbook of South American Archaeology, edited by Helaine Silverman and Williams H. Isbell, 
Springer, New York, 2008. Chungara Revista de Antropología Chilena 43:147-157.

Meggers, B.J., E. Estrada y C. Evans 1965. Early Formative Period of Coastal Ecuador: The Valdivia and Machalilla Phases. Smithsonian Institution Press, Washington DC.

Meggers, B.J. y C. Evans 1965. Cronología relativa y absoluta en la costa del Ecuador. Cuadernos de Historia y Arqueología 11:3-8.

- _ _ 1970. Cómo Interpretar el Lenguaje de los Tiestos. Manual para Arqueólogos, traducido por Víctor Núñez Regeiro. Smithsonian Institution, Washington D.C.

Metcalf, P. y R. Huntington 1995. Celebrating Death. Cambridge University Press, New York.

Montané, J. 1968. Paleoindian remains from Laguna de Tagua Tagua, central Chile. Science 18:1137-1138.

Munizaga, J.R. 1965. Skeletal remains from sites of Valdivia and Machalilla phases. En Smithsonian Contributions to Anthropology, editado por B.J. Meggers, E. Estrada y C. Evans, pp. 219-234. Smithsonian Institution Press, Washington D.C.

_ _ _ 1976. Paleoindio en Sudamérica restos óseos humanos de las cuevas de Palli Aike y Cerro Sota, provincia de Magallanes. En Homenaje al Dr. Gustavo Le Paige, S.J, editado por H. Niemeyer, pp. 19-30. Universidad del Norte, Antofagasta.

. _ _ 1986. El Arcaico en Chile. Chungara 16-17:107-113.

Neves, E.G. 2008. Ecology, ceramic chronology and distribution, long-term history, and political change in the Amazonian floodplain. En Handbook of South American Archaeology, editado por H. Silverman y W.H. Isbell, pp. 359-379. Springer, New York.

Núñez, L. 1975. Programa Paleo-Indio en Chile. Estudios Atacameños 3:89-93.

_ _ _ _ 1976. Informe de actividades del Programa Paleo-Indio. Estudios Atacameños 4:145-149.

_ _ _ _ 2000. Profesor Alberto Rex González, homenaje de la Sociedad Chilena de Arqueología. En Formativo Sudamericano, una Reevaluación, editado por P. Lederberger, pp. 54-56. Editorial Abya-Yala, Quito.

Núñez, L., M. Grosjean e I. Cartajena 2002. Human occupations and climate change in the Puna de Atacama, Chile. Science 298:821-824.

Núñez, L. y B.J. Meggers 1987. Presentación. Estudios Atacameños 8:7.

Rivera, M.A. 2012. Alberto Rex González, reconocimiento a su excelencia en la arqueología. Chungara Revista de Antropología Chilena 44:201-203.

Sandoval, A.C. 2012. Latin American archaeology program (LAAP). Anthropolog Newsletter of The Department of Anthropology National Museum of Natural History Summer:21-23.

Silverman, H. y W.H. Isbell 2008. Handbook of South American Archaeology. Springer, New York.

Watanabe, B. 2012. Betty Meggers: seventy years celebrated. Anthropolog Newsletter of The Department of Anthropology National Museum of Natural History Fall 2009/Winter 2010:6-8.

\section{Nota}

1 Participaron los arqueólogos Pedro Armillas (UNESCO), Mattew Sterling, Clifford Evans, Betty Meggers (Smithsonian), Carlos Zevallos Menéndez (CCE), Francisco Huerta Rendón (Núcleo del Guayas), Olaf Holm (Dinamarca), Emilio Estrada Icaza (Director Museo V. E. Estrada).
The following archeologists participated: Pedro Armillas (UNESCO), Mattew Sterling, Clifford Evans, Betty Meggers (Smithsonian), Carlos Zevallos Menéndez (EHC), Francisco Huerta Rendón (Guayas Nucleus), Olaf Holm (Denmark), Emilio Estrada Icaza (Director Victor Emilio Estrada Museum). 